DOI: $10.2478 / \mathrm{v} 10025-010-0021-\mathrm{x}$

JOURNAL OF WATER

AND LAND DEVELOPMENT

J. Water Land Dev. No. 13a, 2009: 85-101

\title{
Variability of groundwater table, atmospheric precipitation and temperature in swamp habitats of the Zielonka Forest Landscape Park
}

\author{
Sylwester GRAJEWSKI ${ }^{1)}$, Bernard OKOŃSKI ${ }^{1)}$, Andrzej BOCZON'²) \\ 1) University of Life Sciences in Poznań, Department of Forest Engineering, ul. Mazowiecka 41, \\ 60-623 Poznań, Poland, e-mail: sylgraj@up.poznan.pl \\ ${ }^{2)}$ Forest Research Institute in Sękocin Stary, ul. Braci Leśnej 3, 05-090 Raszyn, Poland
}

\begin{abstract}
Results of a study carried out in the Zielonka Forest Landscape Park (central Wielkopolska, middle part of the Warta River catchment) are presented in this paper. The park includes part of a large (15 thousand ha) forest complex called Zielonka Forest. The name pertains to relatively large and dense forest area with small agricultural enclaves situated c. $8 \mathrm{~km}$ north-east of Poznań. Park's landscape of the young glacial type, Pleistocene and Holocene formations, was formed as a result of the Poznań stage of the Baltic glaciation. Dominating habitat types in the park are: fresh mixed deciduous forest (58\%), fresh mixed coniferous forest (25\%), fresh broadleaved forest (10\%), alder and ash-alder swamp forests (4\%).

Analysis of thermal conditions and precipitations was performed for the years 2002-2007 and compared with long-term data from 1987-2007. Annual mean air temperature in the hydrologic year 2003 was lower by $10 \%$ than the long-term mean while in the years 2007, 2006 and 2002 it was higher by 29, 9 and 8\%, respectively. Low air temperature in the year 2003 was the effect of cold winter. In the summer half-year the temperature was definitely above the mean. Hydrologic year 2003 was the coldest but also the driest (64\% of the long-term mean) year in the study period. Variability of ground water tables in swamp habitats was measured in the hydrologic years 2002-2007. During this period the ground water table depth varied from 38 to $181 \mathrm{~cm}$ below ground. Mean lowest stages (116 cm below ground) were noted in the hydrologic year 2006 (with the minimum level of $52 \mathrm{~cm}$ and maximum $178 \mathrm{~cm}$ below ground). The lowest ground water table (181 cm below ground) was, however, noted in 2003 in an experimental plot of the division 85f. The year 2003 was also characteristic for the largest annual amplitude of ground water depths. Obtained results confirm the decisive effect of air temperatures and sums of atmospheric precipitation on ground water table depth in forest swamp habitats. Surprisingly, there was no expected difference in the ground water depth between hydrologic years of extremely different atmospheric precipitations. Smaller variability of ground water level with increasing depth known from the literature was not confirmed either.
\end{abstract}

Key words: air temperature, atmospheric precipitation, ground waters, swamp habitats, the Zielonka Forest Landscape Park 


\section{INTRODUCTION}

Water - an essential component of any living organism - is also a basis for ecosystem persistence. It is also a key factor in the assessment of habitat conditions. Commonly known ecologic network that orders forest habitat types in lowland and upland areas in Poland was based on habitat moisture and fertility. Habitat type in turn determines such basic decisions in forest management like estimation of the economic type of tree stand, species composition of forest crops or selection of the felling type. Therefore, it seems obvious that a diagnosis of the habitat type of forest and its moisture variant should be stable; at least for a single felling cycle in a given tree stand. In fact the assessment may change in much shorter time period due e.g. to changes of water resources in the saturation zone of soil profile.

Human activities, regardless of their typically protective or economic character, should base on precise understanding of present status of the environment. It is also important to know the existing trends of environmental changes and associated threats, both natural and anthropogenic. The method proposed here should, in the author's opinion, enable diagnosis of the present status of forest swamp habitats, most susceptible to ground water fluctuations, and indicate possible threats and potential changes of these habitats.

\section{STUDY AIM}

The aim of this long term study is to verify the hypothesis of unfavourable changes of water resources that take place in the Zielonka Forest Landscape Park. These changes are particularly visible in swamp habitats of the forest. Long observations are necessary to confirm trends of these changes reflecting e.g. in ground water table fluctuations. Hence, results covering relatively short period from 2002 till 2007 presented in this paper are of preliminary character.

Obtained results should enable understanding the effect of meteorological conditions (air temperature and precipitation) on ground water resources in the saturation zone of soil profile in the Zielonka Forest Landscape Park.

\section{STUDY OBJECT}

The Zielonka Forest Landscape Park is situated in central Wielkopolska and in the middle part of the Warta River catchment. The park is part of a large forest complex Zielonka Forest. The name pertains to large (c. 15 thousand ha) dense forest area with small agricultural enclaves situated $8 \mathrm{~km}$ north-east of Poznań. The area is characterised by young glacial landscape of the Pleistocene and Holocene formation. Land relief was formed by the activity of the last glacial period - the so- 
called Poznań stage of the Baltic glaciation (KONDRACKI, 2002). A range of hills called mid-Poznań frontal moraine with a peak of Dziewicza Góra (143 m a.s.1.) runs through southern part of the park. The main element of the area south of the range is a hilly bottom moraine elevated from 90 to 110 (130) $\mathrm{m}$ a.s.l. enriched with valleys and cut by post-glacial channels with many lakes.

The park is covered by forests (78\%), extensively used agricultural lands $(11 \%)$, waters $(4 \%)$, roads and railways $(3 \%)$ and barren lands $(2 \%)$. The area is drained by the Warta tributaries: by Dzwonowski Channel (to the north), by the Trojanka or the Goślińska Struga (to the north-west) and by the Główna River. North-eastern part of the park is drained by the Mała Wełna, western part - by the Goślinka and the Owińska Struga, and southern part - near Czerwonak - is drained by numerous small tributaries of the Warta River. Characteristic feature of the area is the occurrence of many non-drained terrains largest of which spreads from Głębocko to Dziewicza Góra.

The density of hydrographic network in the park is estimated at $0.40 \mathrm{~km} \mathrm{~km}^{-2}$. However, due to hydrotechnical works many natural streams were practically turned into reclamation ditches and joined to the draining system through artificial troughs (ANDERS, 1997). Now, because of long neglected conservation, most reclamation facilities stopped functioning and troughs and ditches are clogged and/or dry. Nevertheless, it is assumed that reclamations could have contributed to a decrease of otherwise small percent of wetlands. Wetlands are now a small part of the total park's area and occur mainly in river valleys. In areas administered by forestry commissions the total area of wetlands being separate forest divisions is c. 155 ha. Moist habitats (Bw, LMw, Lw) cover an area of almost 80 ha and bog habitats $(\mathrm{LMb}, \mathrm{Ol}, \mathrm{OlJ})-320$ ha.

\section{THE HISTORY OF STUDIES ON WATER RELATIONS IN THE PARK}

Recent studies on water relations in the Zielonka Forest Landscape Park had limited scope like the studies on ground water tables in the forest region Potasze (RAPACKI, 1974) or were carried out in relatively small area like catchments of the Hutka $\left(0.52 \mathrm{~km}^{2}\right)$, Potaszka $\left(1.33 \mathrm{~km}^{2}\right)$ (KosturKIEWICZ, 1976; MiLer et al., 1999, 2000a, b) and Dzwonówka Channel $\left(7.3 \mathrm{~km}^{2}\right)$ (KosTURKIEWICZ et al., 1992; MILER, 1994). Studies by Kosturkiewicz (1966-1986) and Rapacki (1971-1973) had typically hydrologic character. Further studies of Kosturkiewicz, Miler and Muratowa (1986-1990), Miler, Liberacki and Plewiński (1997-2000) and Liberacki and Szafrański (2007) were more complex involving both water quantity and quality. Range, methods and results of these studies are described in details in papers cited above.

The Department of Forest Engineering of the University of Life Sciences in Poznań carries comprehensive hydrologic studies (Fig. 1) in the Zielonka Forest 
Landscape Park since 2000. Among others, 132 wells were made to monitor ground water levels and three water gauges were installed in the main stream draining the park - in the Trojanka River. Wells were localised in a way to represent particular age classes of tree stands and dominating types of forest habitats i.e.: fresh mixed coniferous forest (BMśw), fresh mixed deciduous forest (LMśw), fresh broadleaved forest (Lśw), alder (Ol) and ash-alder swamp forest (OlJ). In the year 2003 it was decided to limit the number of sampling points. For further studies of ground waters 50 most representative wells were selected and water levels in the

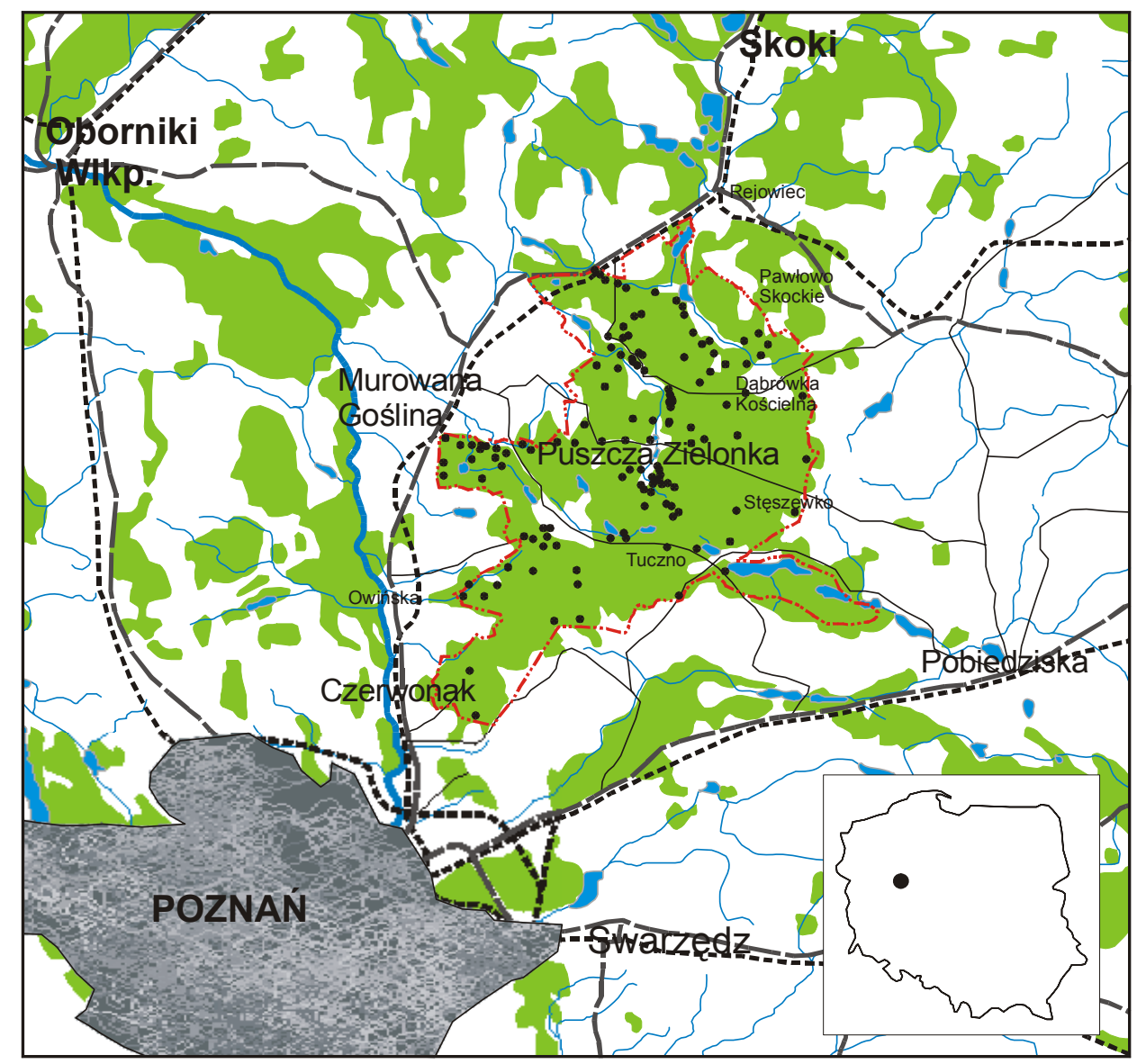

— : - Boundaries of the Zielonka Forest Landscape Park

- Main roads

-1. Main railways

Distribution of groundwater measuring wells

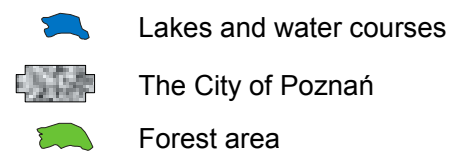

Fig. 1. Location of the Zielonka Forest Landscape Park 
Trojanka River were recorded in a hydrometric section Głębocko closing its catchment.

\section{MATERIAL AND METHODS}

Results of measurements of ground water table made between hydrologic years 2002-2007 in the Zielonka Forest Landscape Park in 7 wells situated in alder swamp forest (Ol) and ash-alder swamp forest (OlJ) were used in this paper (Fig. 2, Tab. 1). Data on precipitation and temperature were obtained from meteorological station of the University of Life Sciences in Poznań localised in central part of the Park in Zielonka (GRODZKI and ZIENTARSKI, 1988-2002; Wyniki..., 2000-2007).

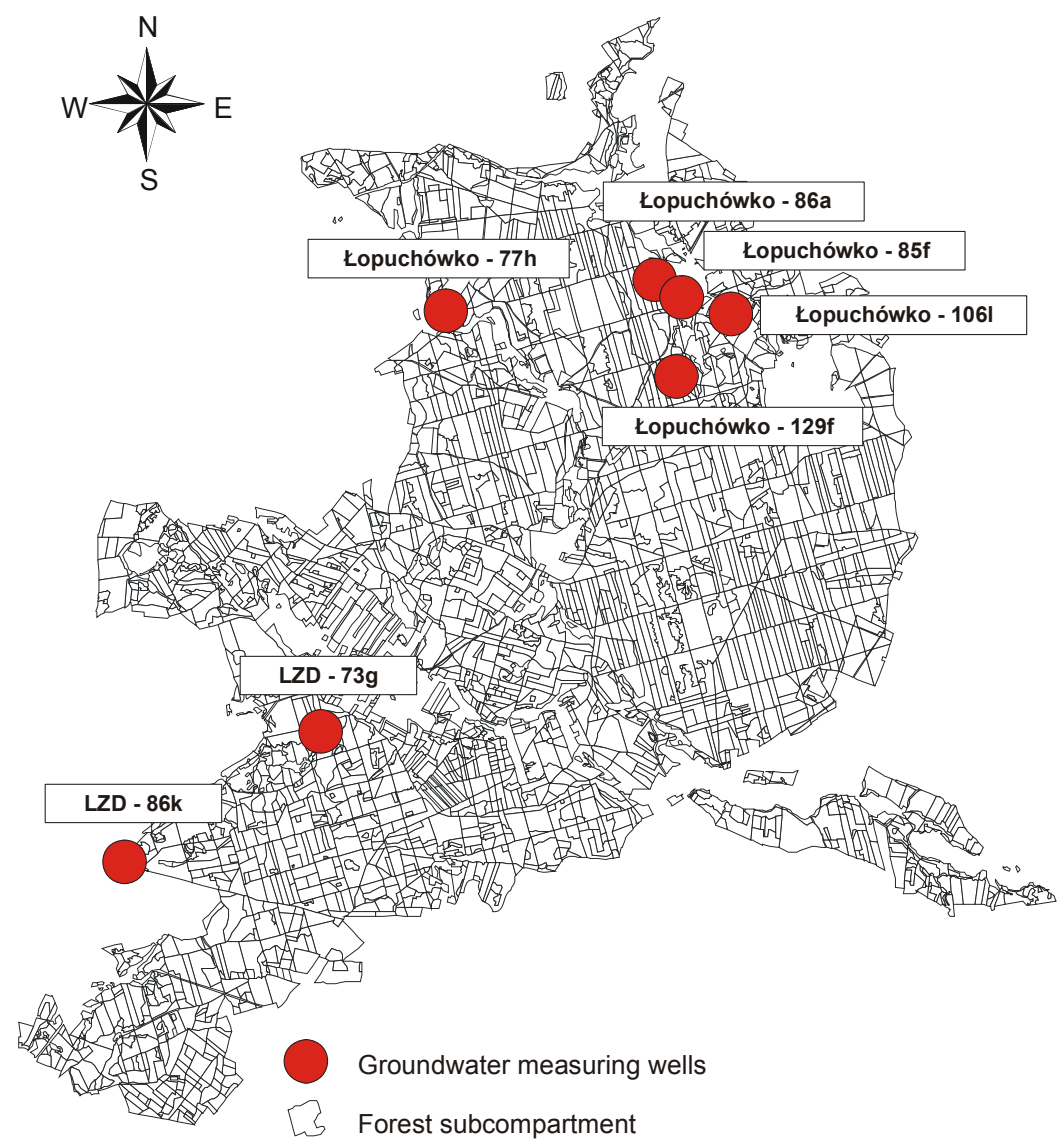

Fig. 2. Distribution of groundwater measuring wells in swamp habitats of the Zielonka Forest Landscape Park 
Table 1. Selected habitat and tree stand characteristics for the experimental plots

\begin{tabular}{|c|c|c|c|c|c|c|c|}
\hline \multirow{2}{*}{ Characteristic } & \multicolumn{7}{|c|}{ Forest commission } \\
\hline & \multicolumn{2}{|c|}{ Zielonka } & \multicolumn{5}{|c|}{ Łopuchówko } \\
\hline Division & $73 \mathrm{~g}$ & $86 \mathrm{k}$ & $129 \mathrm{f}$ & $86 a$ & $85 \mathrm{f}$ & 1061 & $77 \mathrm{~h}$ \\
\hline Forest habitat type & $\mathrm{Ol}$ & OlJ & $\mathrm{Ol}$ & $\mathrm{Ol}$ & $\mathrm{Ol}$ & $\mathrm{Ol}$ & OlJ \\
\hline Soil type & $\mathrm{tn} / \mathrm{py}$ & $\mathrm{tn} / \mathrm{py}$ & $\operatorname{tn} / \mathrm{py}$ & $\operatorname{tn} / \mathrm{gyw}$ & $\operatorname{tn} / \mathrm{gyw}$ & $\mathrm{pl} / \dot{\mathrm{z} p}$ & $\mathrm{pl} / \dot{\mathrm{z} p}$ \\
\hline Tree stand age class & IV & $\mathrm{V}$ & I & I & III & I & IV \\
\hline Forest cover & 0.6 & 1.0 & 1.0 & 0.8 & 0.8 & 0.8 & 0.8 \\
\hline Average diameter at breast height, $\mathrm{cm}$ & 25.5 & 36.5 & 2.5 & 1.5 & 19.0 & 12.0 & 27.5 \\
\hline Average height, $\mathrm{m}$ & 18.5 & 23.5 & 4.0 & 3.0 & 19.5 & 9.5 & 25.5 \\
\hline Standing crop, $\mathrm{m}^{3} \cdot \mathrm{ha}^{-1}$ & 125 & 330 & - & - & 210 & - & 330 \\
\hline Current annual increment, $\mathrm{m}^{3} \cdot \mathrm{ha}^{-1}$ & 3.0 & 5.5 & 5.7 & - & 5.6 & 6.4 & 5.8 \\
\hline
\end{tabular}

Explanations: $\mathrm{Ol}$ - alder swamp forest, $\mathrm{OlJ}$ - ash-alder swamp forest, tn/py - peat on silt (up to $0.8 \mathrm{~m}$ ), tn/gyw peat on lime gyttja (up to $0.8 \mathrm{~m}$ ), pl/żp - loose sand on sandy gravel

Measurements of ground water levels were made at weekly intervals in the hydrologic year 2002 and at monthly intervals afterwards. Monthly means of ground water table depths for the year 2002 and annual means for the whole period 2002-2007 were calculated from obtained results. Variability coefficient (the quotient of standard deviation and the mean) was adopted as a measure of variability.

\section{RESULTS}

\section{METEOROLOGICAL CONDITIONS}

Meteorological characteristics of the park were based on data from the station in Zielonka (52 $33^{\prime} 00^{\prime}{ }^{\prime} \mathrm{N}, 17^{\circ} 06^{\prime} 33^{\prime}{ }^{\prime} \mathrm{E}, 91 \mathrm{~m}$ a.s.1.).

Air temperature

Long-term (1987-2007) mean air temperature is $8.6^{\circ} \mathrm{C}$. The coldest month of the year is January $\left(-1.1^{\circ} \mathrm{C}\right)$ and the warmest - July $\left(19.1^{\circ} \mathrm{C}\right)$. Mean temperature of the summer half-year is $14.9^{\circ} \mathrm{C}$ and that of the winter half-year $-2.3^{\circ} \mathrm{C}$. Mean annual temperatures varied largely over the study period. The coldest was the year 1996 when the annual mean air temperature was $5.9^{\circ} \mathrm{C}$ and the warmest was 2007 with mean temperature of $11.1^{\circ} \mathrm{C}$. Distribution of mean annual temperatures showed a slightly increasing trend more distinct for mean temperatures of summer half-years (Fig. 3). Mean monthly air temperature showed most distinct trend for June and least distinct - for August. Warming of winter months (January-March) did not affect the number of days with snow cover or the maximum thickness of snow cover. 

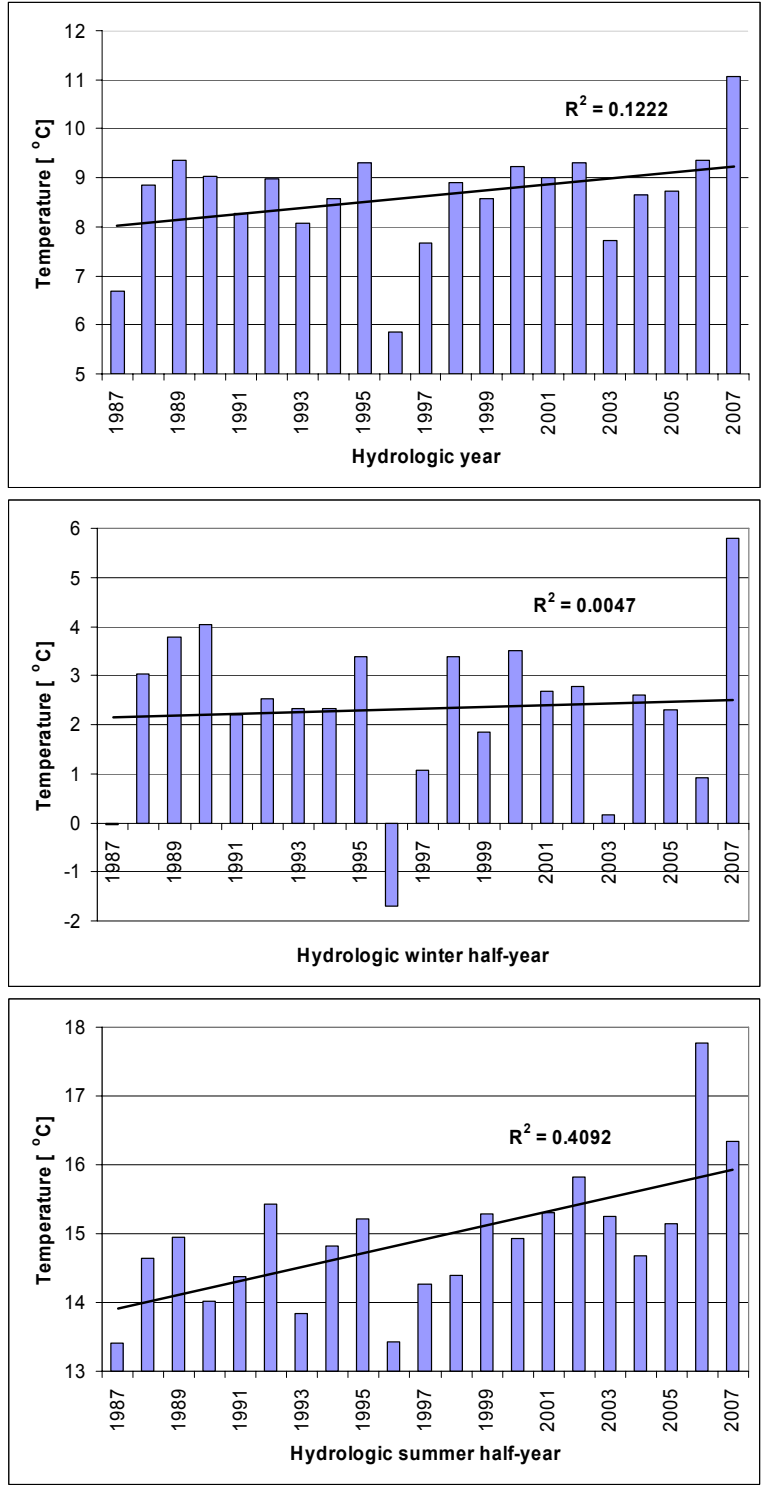

Fig. 3. Mean air temperatures for the period 1987-2007

Hydrologic year 2003 whose mean air temperature was lower by $10 \%$ than the long-term (1987-2007) mean was the coldest year in the study period (Tab. 2). Mean temperatures of 2007, 2006 and 2002 were higher then the long-term mean by 29,9 and $8 \%$, respectively. Low air temperature of the year 2003 was the result of cold winter. In the summer half-year the temperature remained definitely above the mean. 
Table 2. Mean air temperature $T$ and annual precipitation $P$ for the period 2002-2007

\begin{tabular}{|c|c|c|c|c|c|c|}
\hline \multirow{3}{*}{ Hydrological year } & \multicolumn{3}{|c|}{$T,{ }^{\circ} \mathrm{C}$} & \multicolumn{3}{|c|}{$P, \mathrm{~mm}$} \\
\hline & \multicolumn{2}{|c|}{ half-year } & \multirow{2}{*}{$\begin{array}{l}\text { year } \\
\text { XI-X }\end{array}$} & \multicolumn{2}{|c|}{ half-year } & \multirow{2}{*}{$\begin{array}{l}\text { year } \\
\text { XI-X }\end{array}$} \\
\hline & $\begin{array}{l}\text { winter } \\
\text { XI-IV }\end{array}$ & $\begin{array}{c}\text { summer } \\
\text { V-X }\end{array}$ & & $\begin{array}{l}\text { winter } \\
\text { XI-IV }\end{array}$ & $\begin{array}{c}\text { summer } \\
\text { V-X }\end{array}$ & \\
\hline 2002 & 2.8 & 15.8 & 9.3 & 264 & 306 & 570 \\
\hline 2003 & 0.2 & 15.2 & 7.7 & 161 & 180 & 341 \\
\hline 2004 & 2.6 & 14.7 & 8.6 & 186 & 314 & 500 \\
\hline 2005 & 2.3 & 14.2 & 8.3 & 217 & 353 & 570 \\
\hline 2006 & 0.9 & 17.8 & 9.3 & 244 & 310 & 554 \\
\hline 2007 & 5.8 & 16.3 & 11.1 & 287 & 323 & 610 \\
\hline Mean (1987-2007) & 2.3 & 14.9 & 8.6 & 215 & 314 & 529 \\
\hline Min (1987-2007) & -1.7 & 13.4 & 5.9 & 104 & 151 & 341 \\
\hline Max (1987-2007) & 5.8 & 17.8 & 11.1 & 319 & 460 & 654 \\
\hline
\end{tabular}

Atmospheric precipitation

Mean annual precipitation in the years 1987-2007 was $529 \mathrm{~mm}$. The lowest precipitation was noted in $2003(341 \mathrm{~mm})$ and the highest - in $1987(654 \mathrm{~mm})$. Mean long term sum of summer (May-October) rainfall was $314 \mathrm{~mm}$ which made $59 \%$ of the long-term mean annual precipitation. The greatest difference between summer rainfall and annual precipitation was found for the year 1999 when the summer rainfall constituted only $41 \%$ of the annual precipitation. Summer rainfalls contributed most (in as much as $81 \%$ ) to the annual precipitation in 1996 . The lowest summer rainfall $(151 \mathrm{~mm})$ was noted in the year 1992 and the highest $(460 \mathrm{~mm})$ - in 1993. Criteria adopted by KACZOROWSKA (1962) were used to characterise precipitation variability:

- extremely dry year - precipitation below $50 \%$ of the long-term mean,

- very dry year - precipitation from 51 to $74 \%$ of the mean,

- dry year - precipitation from 75 to $89 \%$ of the mean,

- average year - precipitation from 90 to $110 \%$ of the mean,

- wet year - precipitation from 111 to $125 \%$ of the mean,

- very wet year - precipitation from 126 to $149 \%$ of the mean,

- extremely wet year - precipitation above $150 \%$ of the mean.

According to these criteria 9 average years, 2 dry, 3 very dry and 7 wet years were noted between 1987 and 2007 in the station Zielonka. Classification of summer half-years in the same time period showed 8 average years, 5 very dry, 1 extremely dry, 2 wet and 5 very wet years. In view of increasing air temperatures it seems important to estimate the trend in precipitations.

In the annual sums of atmospheric precipitations between 1987 and 2007 one may distinguish two periods (1989-1992 and 2003-2005) of precipitations lower than the mean and one period (1993-2002) with precipitations by almost $100 \%$ 
higher than the mean (Fig. 4). Observed cyclic pattern was not confirmed in the distribution of atmospheric precipitations in winter and summer half-years when the precipitations showed slightly higher variability (Fig. 4). While annual sums did not show any trend, precipitations in the winter half-year tended slightly to increase and those in summer - to decrease.
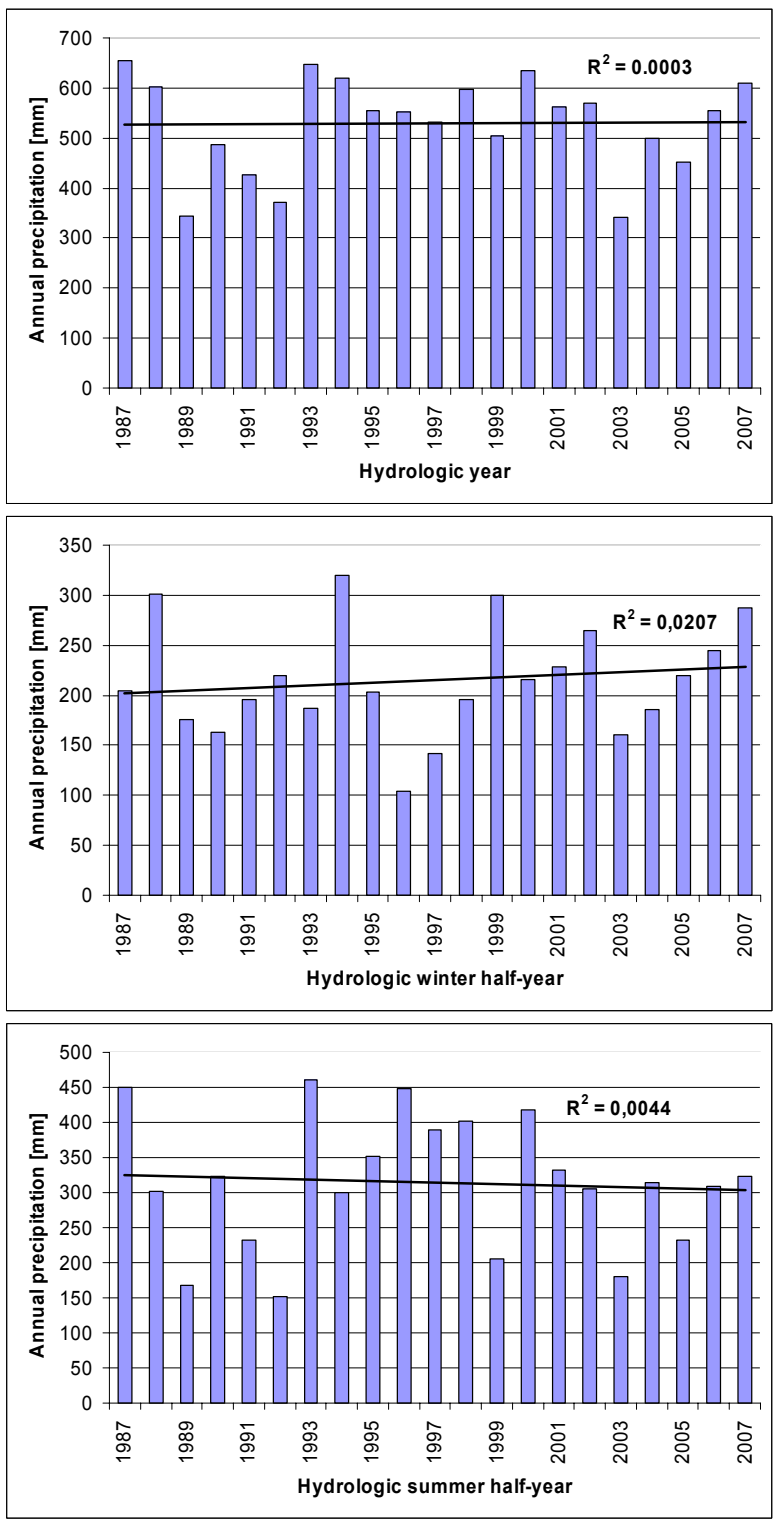

Fig. 4. Annual precipitation for the period 1987-2007 
Variability of ground water levels

Results of measurements of ground water levels and their basic statistics set up according to study plots are presented in Table 3. Ground water tables varied during the study period in a similar way (Fig. 5). Some deviations may be observed in plots situated in divisions $73 \mathrm{~g}, 85 \mathrm{f}$ and $86 \mathrm{k}$. The last plot was characterised by most levelled course of the curve.

Table 3. Selected characteristics of ground water table depth $(h)$ for the experimental plots

\begin{tabular}{|c|c|c|c|c|c|c|c|c|}
\hline \multirow{2}{*}{$\begin{array}{l}\text { Hydrologi- } \\
\text { cal year }\end{array}$} & \multirow{2}{*}{ Characteristics } & \multicolumn{7}{|c|}{ Experimental plots } \\
\hline & & $73 \mathrm{~g}$ & $129 \mathrm{f}$ & $86 a$ & $85 f$ & 1061 & $86 \mathrm{k}$ & $77 \mathrm{~h}$ \\
\hline \multirow[t]{5}{*}{2002} & $\bar{h}, \mathrm{~cm}$ & 86 & 71 & 105 & 106 & 98 & 94 & 139 \\
\hline & $h_{\min }, \mathrm{cm}$ & 58 & 52 & 87 & 7 & 72 & 79 & 102 \\
\hline & $h_{\max }, \mathrm{cm}$ & 130 & 86 & 128 & 160 & 115 & 109 & 165 \\
\hline & $\sigma, \mathrm{cm}$ & 27 & 11 & 15 & 33 & 15 & 10 & 19 \\
\hline & $c_{v}, \%$ & 32 & 16 & 14 & 31 & 15 & 11 & 14 \\
\hline \multirow[t]{5}{*}{2003} & $\bar{h}, \mathrm{~cm}$ & 88 & 70 & 107 & 115 & 95 & 93 & 140 \\
\hline & $h_{\min }, \mathrm{cm}$ & 38 & 41 & 68 & 59 & 62 & 71 & 102 \\
\hline & $h_{\max }, \mathrm{cm}$ & 148 & 112 & 149 & 181 & 126 & 119 & 179 \\
\hline & $\sigma, \mathrm{cm}$ & 40 & 29 & 30 & 44 & 24 & 14 & 28 \\
\hline & $c_{v}, \%$ & 46 & 42 & 28 & 38 & 26 & 15 & 20 \\
\hline \multirow[t]{5}{*}{2004} & $\bar{h}, \mathrm{~cm}$ & 80 & 70 & 100 & 101 & 95 & 87 & 136 \\
\hline & $h_{\min }, \mathrm{cm}$ & 38 & 47 & 71 & 63 & 69 & 71 & 99 \\
\hline & $h_{\max }, \mathrm{cm}$ & 118 & 92 & 133 & 153 & 113 & 99 & 167 \\
\hline & $\sigma, \mathrm{cm}$ & 31 & 15 & 19 & 28 & 14 & 10 & 22 \\
\hline & $c_{v}, \%$ & 39 & 22 & 19 & 27 & 15 & 11 & 16 \\
\hline \multirow[t]{5}{*}{2005} & $\bar{h}, \mathrm{~cm}$ & 99 & 86 & 109 & 117 & 102 & 91 & 152 \\
\hline & $h_{\min }, \mathrm{cm}$ & 59 & 61 & 79 & 82 & 71 & 74 & 131 \\
\hline & $h_{\max }, \mathrm{cm}$ & 149 & 123 & 142 & 168 & 134 & 105 & 180 \\
\hline & $\sigma, \mathrm{cm}$ & 30 & 22 & 18 & 30 & 21 & 10 & 16 \\
\hline & $c_{v}, \%$ & 30 & 25 & 17 & 26 & 20 & 11 & 11 \\
\hline \multirow[t]{5}{*}{2006} & $\bar{h}, \mathrm{~cm}$ & 125 & 92 & 113 & 124 & 107 & 99 & 151 \\
\hline & $h_{\min }, \mathrm{cm}$ & 80 & 52 & 80 & 80 & 93 & 90 & 136 \\
\hline & $h_{\max }, \mathrm{cm}$ & 153 & 118 & 140 & 157 & 136 & 107 & 178 \\
\hline & $\sigma, \mathrm{cm}$ & 23 & 19 & 18 & 26 & 12 & 5 & 12 \\
\hline & $c_{v}, \%$ & 19 & 21 & 16 & 21 & 11 & 5 & 8 \\
\hline \multirow[t]{5}{*}{2007} & $\bar{h}, \mathrm{~cm}$ & 100 & 88 & 108 & 111 & 87 & 83 & 144 \\
\hline & $h_{\min }, \mathrm{cm}$ & 56 & 60 & 83 & 80 & 78 & 71 & 124 \\
\hline & $h_{\max }, \mathrm{cm}$ & 143 & 122 & 137 & 154 & 108 & 103 & 159 \\
\hline & $\sigma, \mathrm{cm}$ & 33 & 20 & 19 & 26 & 10 & 11 & 12 \\
\hline & $c_{v}, \%$ & 33 & 23 & 17 & 23 & 12 & 13 & 9 \\
\hline \multirow[t]{5}{*}{$2002-2007$} & $\bar{h}, \mathrm{~cm}$ & 96 & 79 & 107 & 112 & 97 & 91 & 144 \\
\hline & $h_{\min }, \mathrm{cm}$ & 38 & 41 & 68 & 59 & 62 & 71 & 99 \\
\hline & $h_{\max }, \mathrm{cm}$ & 153 & 123 & 149 & 181 & 136 & 119 & 180 \\
\hline & $\sigma, \mathrm{cm}$ & 33 & 22 & 20 & 32 & 17 & 11 & 19 \\
\hline & $c_{v}, \%$ & 35 & 27 & 19 & 28 & 18 & 12 & 13 \\
\hline
\end{tabular}

Explanations: $\sigma-$ standard deviation, $c_{v}$ - variability coefficient 


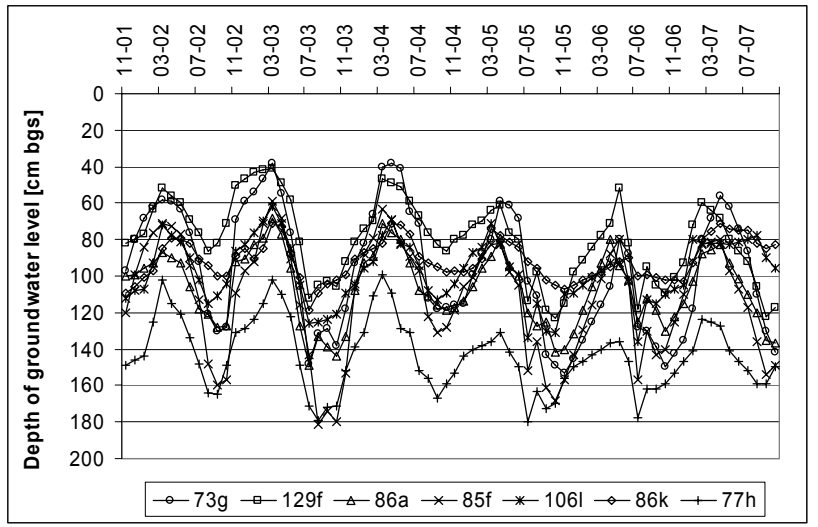

Fig. 5. The dynamics of ground water table depth in experimental plots for hydrologic years 2002-2007

In the years 2002-2007 the ground water table depth in seven experimental plots located in swamp habitats of alder wood and ash-alder wood varied from 38 to $181 \mathrm{~cm}$ below ground (Tab. 3, Figs $6,7,8)$. The highest mean levels $(95 \mathrm{~cm}$ below ground) were noted in the hydrologic year 2004 (at minimum and maximum level of 38 and $167 \mathrm{~cm}$ below ground, respectively). The lowest levels $(116 \mathrm{~cm}$ below ground) were observed in the hydrologic year 2006 (at minimum and maximum level of 52 and $178 \mathrm{~cm}$, respectively). However, the lowest ground water table depth (181 cm below ground) was recorded in 2003 in experimental plot located in division $85 \mathrm{f}(181 \mathrm{~cm}$ below ground). In that year the ground water level fluctuation achieved the largest amplitude of $143 \mathrm{~cm}$.

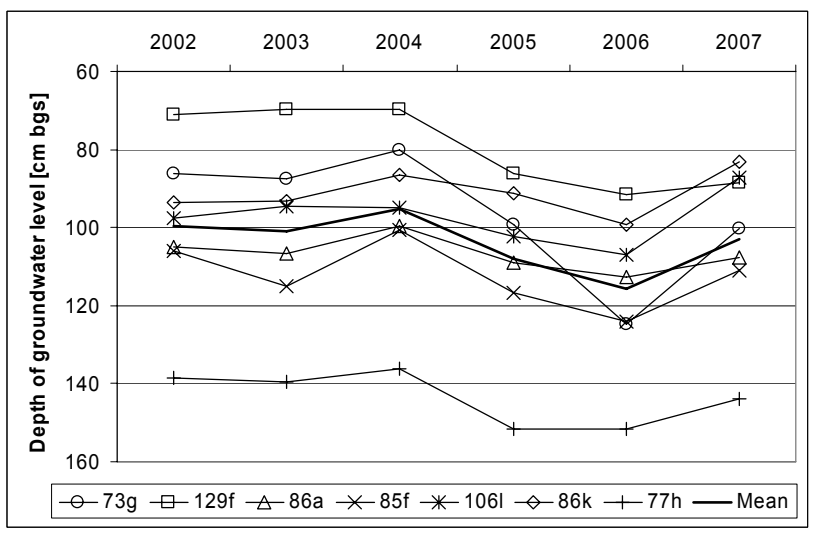

Fig. 6. Annual changes of ground water table depth in experimental plots 


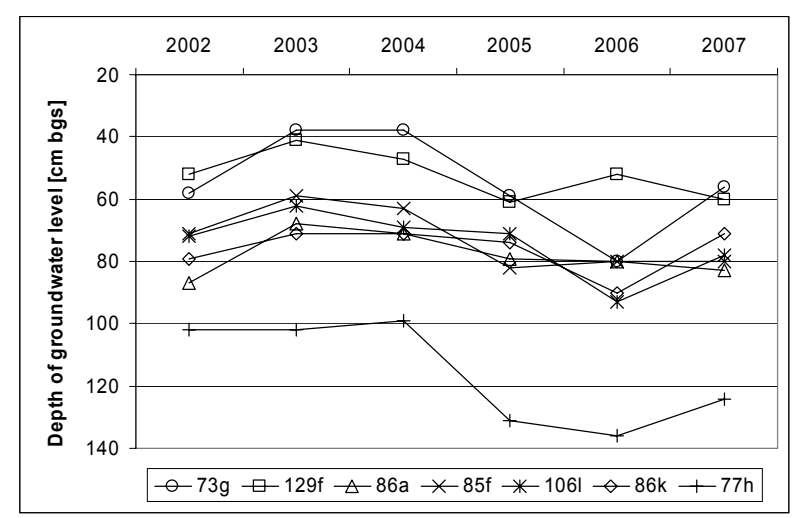

Fig. 7. Minimum ground water table depths in experimental plots

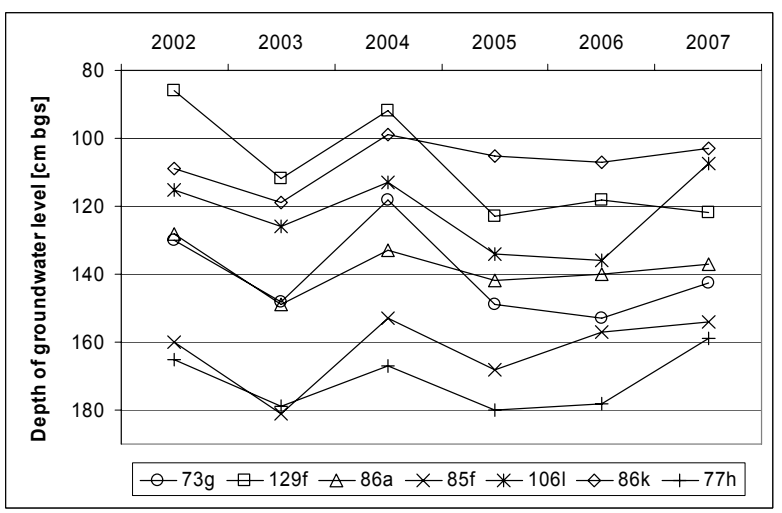

Fig. 8. Maximum ground water table depths in experimental plots

Water reserves in the ground were always recharged in March and April (Fig. 9). There was, however, different dynamics and intensity of water uptake in particular plots. Particularly distinctive were the plots in division $86 \mathrm{k}$ (the smallest dynamics of ground water table depths) and $85 \mathrm{f}$ and $73 \mathrm{~g}$ (intensive water uptake in the vegetation season).

The greatest variability (36\% - Fig. 10) of ground water table depths (expressed as variability coefficient) was associated with the year (2003) of the smallest atmospheric precipitation. The greatest mean variability in the study period was found in a well situated in division $73 \mathrm{~g}\left(c_{v}=33 \%\right)$. In this well the mean annual ground water depths ranged from 80 to $125 \mathrm{~cm}$ below ground with the mean of 96 $\mathrm{cm}$ for the whole study period. The variability coefficient of ground water depths for all wells was $43 \%$ in winter half-years and $37 \%$ in summer half-years. 


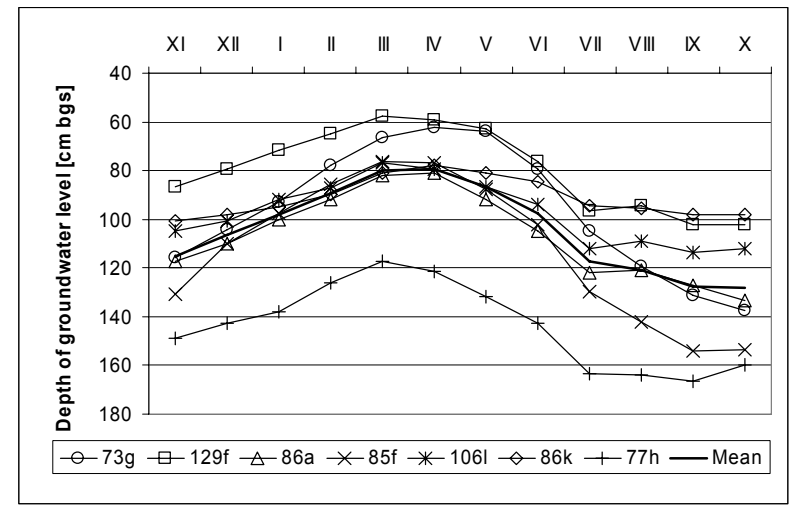

Fig. 9. Monthly variability of ground water table depth for the period 2002-2007

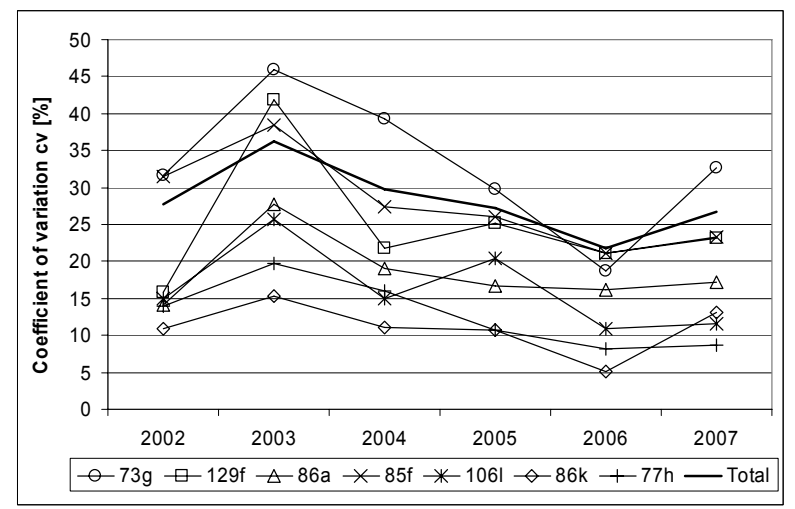

Fig. 10. Variability coefficients $\left(c_{v}\right)$ for ground water table depth

\section{SUMMARY}

The dynamics of ground waters is an outcome of the relations between water input to soil, its retention capacity, evapotranspiration and outflow. Ground water tables, particularly shallow ones, vary annually depending on the course of climate elements. Weather conditions, especially high precipitation variability, make the ground waters dynamics quite variable. These changes are periodical and under favourable conditions the ground water levels return to stages close to the mean. The greatest water dynamics is typical of habitats with shallow ground waters. Ground water rapidly responds to precipitation fluctuations there while the dynamics of deep ground waters is more stable (PIERZGALSKI et al., 2002).

The persistence of bog habitats is determined by the presence of shallow ground waters. Ground water level in the studied habitats was relatively deep. Be- 
cause of too short observation series, however, there are no grounds to confirm the hypothesis of permanent decline of ground water tables in swamp habitats of the Zielonka Forest Landscape Park. Observed tendency of drying out of these habitats might be the effect of e.g. periodical, short-term climate changes (mainly of temperature and atmospheric precipitation). Nevertheless, the tendency of declining ground water table was observed in all sampling points during the study period. Natural swamp habitats are characterised by very shallow ground water tables. Prolonging water deficit and resulting decline of water level might initiate unfavourable changes in these habitats, especially the changes in plant cover.

It is hard to unequivocally determine the reason of declining ground water levels. The study area was subjected to reclamation in the past and now it experiences the increase of air temperature at relatively stable atmospheric precipitations.

Of some importance is also the fact that large forest areas of the park consist of afforested formerly agricultural lands (increased water output for enlarged transpiration of forest plant communities). This issue needs further studies and observations.

Obtained results confirm the decisive impact of air temperature and sums of atmospheric precipitation on ground water level in forest swamp habitats. A lack of expected large difference in ground water table depths among the extremely different in precipitation hydrologic years 2002, 2002 and 2005 raises some doubts. Interestingly, the decrease of ground water depth variability with water level depth known from the literature was also not confirmed. All wells showed remarkable similarity in that aspect. The smallest variability during the study period was found in wells localised in ash-alder woods $\left(c_{v}=12-13 \%\right)$ and in the tree stands in the first age class $\left(c_{v}=18-19\right.$ to $\left.27 \%\right)$.

\section{CONCLUSIONS}

Performed studies and observations allow for drawing the following conclusions:

1. Annual sums of atmospheric precipitation in the years 1986-2007 are quite variable and do not show directional changes. Minimum positive trend was found for the sums in winter half-years and negative - for the summer ones. Worrying, though small, might be the declining trend of precipitation sums in April, June and July.

2. No particularly long rainless periods were recorded in the study period. Unfavourably small number of intensive precipitations i.e. such that could efficiently recharge soil profile was, however, noted.

3. Air temperatures measured at the station in Zielonka (1986-2007) showed slightly increasing trend. Changes were more visible in the summer half-years of particular hydrologic years. Increase of temperature and evaporation without com- 
pensation by increased input from atmospheric precipitation pertains, to a different degree, to all months of the hydrologic year.

4. Mean annual ground water depth in swamp habitats of the Zielonka Forest Landscape Park in the years 2002-2007 ranged from 79 to $144 \mathrm{~cm}$ below ground which evidences their considerable drying. It is thus reasonable to postulate fast actions aimed at protecting these habitats through e.g. limiting and slowing down water outflow and increasing water retention in these areas.

5. In view of unfavourable climatic changes current monitoring of surface and ground waters is necessary to maintain persistence and stability of ecosystems (not exclusively swamp habitats) in the Zielonka Forest Landscape Park.

\section{REFERENCES}

1. Anders P., 1997. Puszcza Zielonka. (Zielonka Forest). Wielkopol. Bibl. Krajozn., 17. Poznań, Wydaw. Pozn.: 109.

2. GRODZKI M., ZIENTARSKI J., 1988-2002. Wyniki obserwacji meteorologicznych w Zielonce w latach 1986-1999. (Results of meteorological observations in the years 1986-1999). Rocz. AR Pozn. Leśn., 193: 23-54, 207: 17-45, 219: 3-32, 231: 47-74, 241: 43-74, 255: 87-115, 258: 81-97, 273: 3-20, 287: 19-36, 297: 3-20, 305: 25-42, 311: 47-77, 326: 27-57, 345: 17-36.

3. KACZOROwSKA Z., 1962. Najsuchsze i najwilgotniejsze pory roku w Polsce w okresie 1900-1959. (The driest and wettest seasons in Poland in the years 1900-1959). Prz. Geofiz., 7/15: 3.

4. KONDRACKI J., 2002. Geografia regionalna Polski. (Regional geography of Poland). Warszawa, PWN.

5. Kosturkiewicz A., 1976. Zmienność odpływów z małych zlewni o różnym stopniu lesistości. (Outflow variability in small catchments of various forest coverages). PTPN Pr. Kom. Nauk Rol. Kom. Nauk Leśn., 17: 67-73.

6. Kosturkiewicz A., Miler A., Muratowa S., 1992. Gospodarka wodna i jakość wód w małych zlewniach stawowych w regionie Wielkopolski. (Water management and water quality in small pond catchments in the Wielkopolska region). Zesz. Nauk. AR Wroc. Melior., 40, 211: 145-168.

7. LiBERACKi D., SZAFRAŃSKi Cz., 2007. Jakość wód w małych ciekach leśnych na terenie Puszczy Zielonka. Monitoring funkcjonowania i przemian geoekosystemów jeziornych. (Water quality in small forest streams in Zielonka Forest. Monitoring of the functioning and changes in lake geoecosystems). Międzyzdroje, 9-11 X 2007: 45-46.

8. Miler A., 1994. Modelowanie matematyczne zdolności retencyjnych małych zlewni nizinnych. (Mathematical modelling of water retention capacities of small lowland catchments). Rocz. AR Pozn. Rozpr. Nauk., 258: 91.

9. Miler A., LiberACKi D., PlewiŃSKi D., 1999. Obieg wody i wybrane wskaźniki jej jakości w dwóch mikrozlewniach o zróżnicowanym zalesieniu. Water cycling and indices of its quality in two microcatchments of different forest coverage. Rocz. AR Pozn., 310 Melior. Inż. Środ., 20 P. 1: 443463.

10. Miler A., LiBeracki D., PlewiŃSKi D., 2000a. Ilościowa i jakościowa ocena odpływu z dwóch kontrastowych pod względem zalesienia mikrozlewni nizinnych. (Quantitative and qualitative assessment of water outflow from two lowland microcatchments differing in percent of forest cover). Zesz. Nauk. AR Krak., 365 Ses. Nauk., 72: 435-445.

11. Miler A., LiberACKi D., PlewiŃSKi D., 2000b. Ilościowa i jakościowa ocena stosunków wodnych w dwóch odmiennych pod względem zalesienia małych zlewniach nizinnych. (Quantitative and 
qualitative assessment of water relations in two lowland microcatchments differing in percent of forest cover). Pr. Kom. Nauk Rol. Kom. Nauk Leśn., 88: 81-92.

12. Pierzgalski E., BoczoŃ A., TyszKa J., 2002. Zmienność opadów i położenia wód gruntowych w Białowieskim Parku Narodowym. (Variability of precipitation and ground water depth in the Białowieża National Park). Kosmos, 4: 415-425.

13. RAPACKI L., 1974. Badania zmienności poziomu wód gruntowych w środowisku leśnym na przykładzie leśnictwa doświadczalnego Potasze. (Studies on the variability of ground water depth in forest habitat - an example of experimental forest region Potasze). Poznań, AR Phd. Thesis.

14. Wyniki obserwacji meteorologicznych na stacji w Zielonce w roku 2000, 2001, 2002, 2003, 2004, 2005, 2006, 2007. (Results of meteorological observations at the station Zielonka in the years 2000 -2007). Poznań, Kat. Hod. Lasu UP maszyn.

\section{STRESZCZENIE}

\section{Zmienność położenia wód gruntowych, opadów atmosferycznych i temperatury na siedliskach bagiennych Parku Krajobrazowego Puszcza Zielonka}

Słowa kluczowe: opady atmosferyczne, Park Krajobrazowy, Puszcza Zielonka, siedliska bagienne, temperatura powietrza, wody gruntowe

W pracy przedstawiono wyniki badań prowadzonych na terenie Parku Krajobrazowego Puszcza Zielonka, położonego w centralnej części Wielkopolski i w środkowej części dorzecza Warty. Park obejmuje część dużego (ok. 15 tys. ha) kompleksu leśnego, jakim jest Puszcza Zielonka. Nazwą tą przyjęto określać stosunkowo rozległy, zwarty teren leśny z niewielkimi enklawami rolniczymi, leżący ok. 8 km na północny wschód od granic Poznania. Krajobraz parku typu młodoglacjalnego, formacji plejstoceńskiej oraz holoceńskiej ukształtowany został w wyniku działania poznańskiego stadiału zlodowacenia bałtyckiego. Dominującymi typami siedliskowymi lasu na terenie Parku są: las mieszany świeży (58\%), bór mieszany świeży (25\%), las świeży (10\%) oraz olsy (4\%).

Analiza warunków termiczno-pluwialnych przeprowadzona została dla lat hydrologicznych 2002-2007 na tle wielolecia 1987-2007. Średnia roczna temperatura powietrza $\mathrm{w}$ roku hydrologicznym 2003 była niższa od średniej z wielolecia (1987-2007) o 10\%, natomiast w latach 2007, 2006 i 2002 była wyższa odpowiednio o 29,9 i 8\%. Biorąc pod uwagę półrocza hydrologiczne, należy zwrócić uwagę, że niska temperatura powietrza w 2003 r. była wynikiem chłodnej zimy. W półroczu letnim temperatura utrzymywała się zdecydowanie powyżej średniej. W rozpatrywanym okresie badawczym rok hydrologiczny 2003 okazał się nie tylko jednym z najzimniejszych, ale również najsuchszym rokiem wielolecia 1987-2007 (64\% średniej wieloletniej). Zmienność stanów wód gruntowych w siedliskach bagiennych mierzono w latach hydrologicznych 2002-2007. W tym okresie głębokość zalegania wód gruntowych wynosiła od 38 do $181 \mathrm{~cm}$ p.p.t. Średnio najniższe 
stany (116 cm p.p.t.) zaobserwowano w roku hydrologicznym 2006 (minimalny stan 52, maksymalny $178 \mathrm{~cm}$ p.p.t.). Jednak najniższy stan wody gruntowej odnotowano w 2003 r. na powierzchni doświadczalnej zlokalizowanej w oddziale $85 \mathrm{f}$ (181 cm p.p.t.). Rok 2003 wyróżnił się również największą roczną amplitudą stanów wód gruntowych. Uzyskane wyniki badań potwierdzają decydujący wpływ temperatury powietrza i sumy opadów atmosferycznych na kształtowanie zwierciadła wód gruntowych w leśnych siedliskach bagiennych. Wątpliwości budzi brak spodziewanej znacznej różnicy w głębokości zalegania wód gruntowych między skrajnymi pod względem wysokości opadów atmosferycznych latami hydrologicznymi. Interesujący jest również brak potwierdzenia znanej z literatury przedmiotu zależności zmniejszania się dynamiki zmienności stanów wód gruntowych wraz z głębokością ich zalegania.

Reviewers:

Assist. prof. Zbigniew Kowalewski

Prof. Edward Pierzgalski 